\title{
Determinants of Lighting Energy Transitions in Rural Ethiopia: Lessons from Mida Oromo and Wonisho Districts of Ethiopia
}

\author{
Kindeye Fenta Mekonnen (Corresponding author) \\ Center for Environment and Development, College of Development Studies \\ Addis Ababa University, P.O. BOX: 1176, Addis Ababa, Ethiopia \\ E-mail: mkindeyefenta@yahoo.com
}

Yohannes Abera

Center for Environment and Development, College of Development Studies

Addis Ababa University, P.O. BOX: 1176, Addis Ababa, Ethiopia

Received: March 28, 2019 Accepted: April 16, 2019 Published: July 25, 2019

doi:10.5296/emsd.v8i3.15151 URL: https://doi.org/10.5296/emsd.v8i3.15151

\begin{abstract}
Modern renewable energy is an important tool to achieve socio-economic transformation, particularly in rural areas of developing countries like Ethiopia. However, most people do not access modern energy and thus providing it is one of the daunting tasks that the government has faced. Knowing energy choice of households is one of the important factors to bring energy transition. However, limited studies are undertaken in the Country on this area. Thus, this paper tried to address the gap by investigating factors affecting households lighting energy choice by taking sample of 442 households in Mida Oromo and Wonisho Districts of Ethiopia. Both descriptive and inferential statistics were employed for analyzing the data. The result shows that households consume a range of traditional, transitional and modern lighting energy sources available in their areas. Wealthy households prefer lighting energy sources that are clean and relatively expensive including, grid electricity and solar energy unlike households in lower income category who opt to cheap and easily available energy sources. The study further highlighted that income is not the only factor affecting household energy transitions. Family size, access to market and road infrastructure, asset of the household and the district of the households, mobile and radio ownership and education attainment of the head or family members are found to be an important determinants affecting energy transition
\end{abstract}


of rural households. The study concluded that any program that aim to provide modern lighting energy sources need to consider all these diverse factors and local contexts.

Keywords: Energy transition, Primary lighting energy, Multinomial logit model, Determinants of energy transitions

\section{Introduction}

Access to modern energy is one of the tools to achieve socio-economic transformation in sustainable manner (Dawit et al., 2015; Schelly, 2014; Zereay etal., 2014) though it cannot bring development by itself (Abdul-Salam, 2014; Ahlborg et al., 2011; Bawakyillenou, 2007; Schelly, 2014). Many people, however, rely on traditional energy sources that have adverse health and environmental impacts. In 2013, for instance, about 1.2 billion lack access to electricity and 2.64 billion people are relying on traditional biomass for cooking (IEA, 2017). Sub-Sahara Africa (SSA) and South Asia accounted 80\% of these people (Abdul-Salam, 2014; Malla and Govinda, 2014; Kowsari, 2013). Median rural and urban access in SSA is about $17 \%$ and $59 \%$ respectively, showing that lack of electricity service is disproportionately higher in rural settlements (IEA, 2017; Abdul-Salam, 2014; Arora et al., 2011).

Like SSA countries, Ethiopia overwhelmingly relies on traditional energy sources. Ethiopia's energy status lag behind other countries by many standards. Modern energy represents only less than $10 \%$ of the total energy consumption (CSA and the WB, 2013; Howell, 2011; IEA, 2017). Per capita energy consumption is about $200 \mathrm{kWh}$ per year, far lower than the SSA average of $517 \mathrm{kWh}$ and fraction of the world average of $2800 \mathrm{kWh}$ per person (Zereay etal., 2014). Ethiopia is ranked 62 out of 64 countries on the Energy Development Index (EDI). Similarly, on Oxford University's Multidimensional Energy Poverty Index (MEPI), Ethiopia scored 0.9 showing the suffering of the country from "acute energy poverty" (Nussbaumer et al., 2012). The country suffers from energy poverty despite its considerable energy potential. It has the largest hydropower potential (around 45000MW) in Africa after Democratic Republic of Congo; immense geothermal, wind and solar energy; and energy from wood and agricultural waste (MoWE, 2016).

Lack of modern energy is, in particular, immense in rural areas of Ethiopia. Thus, addressing energy poverty and enhancing livelihood of its people through modern energy provision pose challenges. Electrification through extension of the national grid and provision of off-grid modern energy technologies are the two strategies employed by the government (Lighting Africa Program, 2013; Howell, 2011). Extension of the national grid to rural areas is the preferred approach (Overseas Development Institute, 2015). However, remoteness, isolation, and low electricity demand of rural communities make them very unlikely to be reached by the extension of the grid (MoWE, 2016; Yonas et al, 2013). Thus, the ideal solution is provision of off-grid renewable energy technologies, including solar system.

Information on factors influencing rural household energy transitions is limited in Ethiopia. Many researchers emphasized a particular energy source and did not consider households' modern energy portfolio and transitions in consumptions of energy (Getaw etal., 2015; Gebreegziabher et al, 2011). Most studies gave emphasize to urban areas and cities of 


\section{Macrothink}

Ethiopia and those that investigated fuel choice focus on cooking energy transitions (Yonas et al, 2013; Beyene and Koch, 2012). There are no comprehensive and in-depth studies on lighting energy transition in rural areas. This study is thus aims to inform policy makers in the energy sector by providing comprehensive analysis of the household motivation to choose particular lighting fuel and their reason to substitute fuels. In general, the objective of the study is to assess energy transition towards clean, reliable, modern and sustainable energy in the rural areas of Ethiopia by taking sampled households in two Woredas (Districts).

\section{Methods}

\subsection{Description of the Study Areas}

This research was undertaken in Mida Oromo Woreda of North Shewa Zone of Amhara Region and Wonisho Woreda of Sidama Zone of Southern Nations, Nationalities and People Region (SNNP) of Ethiopia. The two Woredas are diverse in geography, religion, culture and economic activity implying that they provide opportunities to explore the spatial, cultural and economic aspects of energy transition. Demographically, Mida Oromo has a total population of 93,729 ; and 7,049 or $7.52 \%$ are urban inhabitants. Around $88.41 \%$ of the population practiced Orthodox Christianity while $11.51 \%$ are Muslims (CSA, 2007; Mida Oromo Economic Office, 2017). Wensho Woreda has a total population of 89,662; and 2,039 or 2.27\% of its population are urban dwellers (CSA, 2007; Wonisho Woreda Economic Office, 2017). In terms of religion, $70.47 \%$ are protestant Christians, $12.17 \%$ follow traditional religions, $8.84 \%$ are Muslims, $1.93 \%$ and $1.42 \%$ practiced Catholic and Orthodox Christianity, respectively (CSA, 2007).

Households in Wonisho Woreda are primarily relying on production of cash crops such as coffee, chat, and vegetables while crop production is the primary economic activity in Mida Oromo. Households in the two districts are also significantly varied in terms of social and cultural conditions.

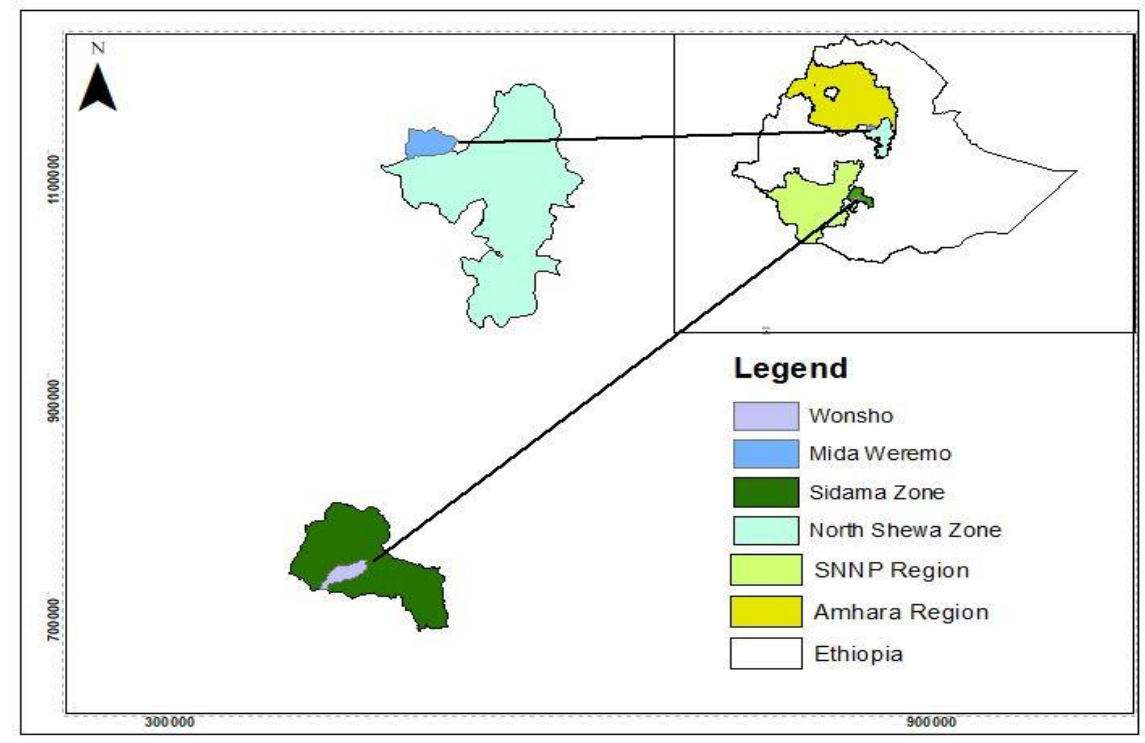

Figure 1. Map of the Study Area 


\subsection{Research Design and Sampling}

Multi-stage sampling was pursued to select sample households. The two Woredas were selected among 41 districts in the two zones (22 in North Shewa Zone and 19 in Sidama Zone) respectively taking the energy profiles into account. Nine villages (Kebelles), four from Mida Oromo Woreda and five from Wonisho, were selected based on households' energy menu collected by the energy offices of the two Districts. Stratified sampling was employed to divide villages taking their access of modern energy as parameter. As Berg (2001) argued, a stratified sample is used whenever researchers need to ensure that a certain segment of the identified population under examination is represented in the sample. Preliminary investigations of the villages show that some of them have high concentration of range of energy choices unlike others who have low energy portfolio. Here, we have two strata: villages with diverse energy sources and others with relatively limited choices. Using systematic random sampling in each stratum, the sampled households were drawn in each village and the sample size was assigned proportional to the population of each village using the CSA (2007) population and housing census report as presented in table 1 below.

Table 1. Sampled Kebelles and Household Numbers of the Research Areas

\begin{tabular}{|c|l|l|l|}
\hline Administrative tier & Population & Households & Sampled Households \\
\hline Mida Oromo Woreda & $\mathbf{8 6 6 8 0}$ & $\mathbf{2 0 1 4 6}$ & $\mathbf{2 3 1}$ \\
\hline Remana Dire & 6915 & 1566 & 88 \\
\hline Rema 01 & 3765 & 1157 & 65 \\
\hline Tebabitna Kure Bayemoda & 2255 & 541 & 31 \\
\hline Weyblena Afer Bayne & 3440 & 835 & 47 \\
\hline Wensho Woreda & $\mathbf{8 7 , 6 2 3}$ & $\mathbf{1 8 , 2 1 8}$ & $\mathbf{2 1 1}$ \\
\hline Menafesha & 6,863 & 1,434 & 54 \\
\hline Kiliye & 5,312 & 1,097 & 41 \\
\hline Halekna & 6000 & 1217 & 45 \\
\hline Kinante & 4719 & 946 & 35 \\
\hline Bokaso & 4785 & 983 & 36 \\
\hline Total sampled Households & & $\mathbf{9 7 6 6}$ & $\mathbf{4 4 2}$ \\
\hline
\end{tabular}

The sample size is determined by taking the optimum number necessary to enable valid inferences to be made about the population (Marshall, 1996). Kothari formula was employed (Kothari, 2004):

$$
\begin{aligned}
& \mathrm{n}=\left(\mathrm{Z}_{\alpha} / 2\right)^{2} \text { P.Q.N } \\
& \mathrm{e}^{2(\mathrm{~N}-1)+\mathrm{Z}}\left({ }_{\alpha} / 2\right)^{2} \text { P.Q }
\end{aligned}
$$

Where, $\mathrm{n}=$ Sample size;

$\alpha / 2=$ two tailed critical value, at $95 \%$ confidence interval;

$\mathrm{Z}=$ Confidence Interval (1.96) 
$\mathrm{P}=$ probability of adopting modern energy;

$\mathrm{Q}=1-\mathrm{p}$

$\mathrm{N}=$ Sample frame;

$\mathrm{e}=$ marginal error between the sample and the population size $(0.05)$.

$\mathrm{n}=384$, and the researcher added other 59 samples $(15 \%$ of $\mathrm{n})$ to provide more precise estimation of the population and thus a total of 442 households were undertaken to the final calculation.

To collect the data, structured and semi-structured Household Survey questionnaire was developed and implemented. In addition, 32 expertise and representatives of institutions who are knowledgeable on all aspects of energy in the study areas were approached as key informants. Officials from the Saving and Credit Institutions; Bureau of Energy and water; representatives from NGOs, Development Agents (Das); enterprises; elders, religious leaders, youth associations, business representatives and other expertise were contacted. Focus Group Discussion (FGD) was undertaken to know the perceptions, ideas, opinions, and thoughts of participants about issues pertinent to modern energy in general and solar energy in particular. Ten FGDs (5 in each District) were held and this size was determined once the researcher felt that the collection of more data no longer have additional worth, the information was saturated. Books, journals, articles, legal documents, internet sources were employed as secondary sources of data. The information gathered from these sources employed to consolidate the statistical results. This is followed by running multinomial regression model to identify major determinants of lighting energy transition. The data was coded, entered, and analysed using Statistical packages (SPSS 20, CsPro, and STATA 13).

\subsection{Modelling Major Determinants of Household Energy Transitions}

Conventionally, most studies associate energy transition and modern energy technology adoption with economical factors. A more recent strand of literature has included non-economic factors as equally important (Zereay et al., 2013; He, 2014). Factors, including socio-economic, health, cultural and local environment affect household's fuel choices (Malla and Govinda, 2014; Peters and Maximiliane, 2015; Zereay et al., 2013). Understanding of all these factors is highly cumbersome implying the need to be selective based on the energy technology being investigated, the location, and the researcher's preference (Mwangi, Margaret and Samuel Kariuki, 2015).

Modelling of households' energy transition is investigated under the general framework of consumer theory (Baiyegunh, 2014). Multinomial logit Model (MNL) is employed in dealing with household lighting energy choice because of its ability to perform better with discrete choice studies as households' choice of lighting energy involves multiple response (Baiyegunh, 2014; Osiolo, 2009; Reddy, 2004).

Households choose one energy source among a set of mutually exclusive and highly differentiated lighting fuels. In many rural areas of the country people use diverse lighting energy sources, including electricity, kerosene, firewood, dry cells and solar PVs 


\section{Macrothink}

(Gebreegziabher et al., 2011). In making selection of a particular lighting energy, households are assumed to act to maximize utility (McFadden, 1974). The Mc Fadden's Model can be expressed as:

$$
Z_{i j}^{*}=\alpha w_{i}+\Upsilon i j, \mathrm{j}=1,2,3, \ldots \mathrm{K} ; \mathrm{i}=1,2,3 \ldots, \mathrm{N}
$$

Where;

$Z_{i j}^{*}$ is the benefit associated with using a particular fuel, and is assumed to be linear function of set of observed variables, with $\mathrm{i}$ individuals or households; $\mathrm{j}$ mutually exclusive fuel choices for lighting which is electricity, solar, dry cell and kerosene;

$\alpha$ is vector of coefficients to be estimated;

$\mathrm{w}$ is a set of economic and non-economic variables;

? is a disturbance term.

If household makes choice $j$ in particular, then we assume that $Z_{i j}^{*}$ maximum among the four lighting energy sources; i.e $j$ is chosen if $Z_{i j}^{*}>Z_{i j}^{*} k$ if and only if j\#k.

The energy choice is defined as a vector $\mathrm{Zi}=[\mathrm{Zij}]$ of four dummy variables taking value 1 if the household choice falls on the $j$ th alternative, and value 0 otherwise. The probability that $\mathrm{j}$ is included in the i's choice set is pi $\left(z^{*}>1\right)$. This fuel choice probability can be expressed as:

$$
p i(Z=j)=\frac{\exp (a i j w i)}{\sum_{j=0}^{m} \exp (a i j w i)} \quad \mathrm{j}=1,2,3,4
$$

Equation 2 is estimated using the maximum likelihood method. To estimate coefficients of w, the following likelihood function is maximized:

$$
L(\theta)=\sum_{i=1}^{N} \sum_{j=1}^{J} 1\{z i j\} \cdot \operatorname{lnpj}(w i ; \theta)
$$

Where; $L(\theta)$ is the $\log$ likelihood function, $\theta$ is set of parameters to be estimated.

The MNL model relies on the independence of irrelevant alternatives (IIA) assumption to obtain unbiased parameter estimates. To demonstrate the validity of the IIA assumption, Hausman test was used. The Hausman test enables to detect endogenous regressors in a regression model. And, the estimated coefficients of MNL model provide only the direction of effect of independent variables on dependent variables. Thus, the marginal effect was obtained through running Stata version 13.

\section{Results and Discussion}

This section begins with brief introduction of energy portfolio of households followed by comparison of choices to particular lighting energy source. Discussion of major factors 
mediating households' decisions to use particular energy type for lighting activities are integral part of the section and uses this as a springboard to interrogate the explanatory power of the energy ladder and energy stacking theories.

\subsection{Households Energy Portfolio}

Ten major energy sources are identified in the study areas and that their utilization varies from districts to districts and from household to household. Households use two or more combinations of these energy sources. The following table 2 summarizes energy sources in the two Districts.

Table 2. Energy Portfolio of Households

\begin{tabular}{|l|l|l|l|}
\hline \multirow{2}{*}{ Energy Source } & \multicolumn{2}{|l|}{ Percentage of Households (Each District) } & \multirow{2}{*}{ Both Districts } \\
\cline { 2 - 3 } & Mida Oromo & Wonisho & \\
\hline Solar & 47.30 & 24.424 & 36.463 \\
\hline Bio-gas & 3.74 & 2.77 & 3.275 \\
\hline ICS & 15.768 & 4.148 & 10.262 \\
\hline Electricity & 36.099 & 12.903 & 25.109 \\
\hline Kerosene & 4.98 & 76.498 & 38.864 \\
\hline Dry-Cell & 75.934 & 78.34 & 77.074 \\
\hline Firewood & 99.586 & 99.54 & 99.563 \\
\hline Charcoal & 18.672 & 4.6 & 12.008 \\
\hline Animal Dung & 31.54 & 0.922 & 17.030 \\
\hline Crop Residue & 53.112 & 27.189 & 40.829 \\
\hline
\end{tabular}

Table 2 shows that households' do not rely on single energy system; they diversify their energy sources combining traditional, transitional and modern sources available in their respective areas. Discussions with households reveal that they do not necessarily abandon old ones when adopting a new energy source. They often tend to stack and keep all energy sources. Households with modern energy faced frequent pour outages and thus continue to keep other sources. Percentage of households owning one or more types of energy sources varies along the two study areas. The biggest variation is in their deployment of energy from animal dung and kerosene. While percentage of households' using kerosene and animal dung is $5 \%$ and $31.5 \%$ in Mida Oromo, corresponding figures to Wonisho Woreda are $76.5 \%$ and $0.92 \%$, respectively. This could be explained by the fact that people in Mida Oromo have more cattle stocks in the first place and households in Wonisho collect cash crops which provide opportunity in affording cost of kerosene. There are also pronounced geographical variations in size of households owning charcoal or crop residue. In contrast, size of households consuming dry-cell batteries, bio-gas and firewood is more or less similar in the two study areas. Firewood continued as dominant energy source in both districts.

Households' diversification of energy shows that they consider issues of sustainable energy supply in their decision and make effort to ensure their energy demand is secured. Households realize that extensive dependence on single energy source could disrupt their life if its supply is exhausted that ultimately usher in energy crisis. Table 2 also demonstrates that 
local contexts and circumstances, including availability and affordability of the energy source shapes household's choice.

\subsection{Lighting and Cooking Energy Choice}

Households use variety of energy sources to undertake cooking and lighting activities. Discussion with key informants reveals that, demand for particular energy source is determined by its cost, availability, convenience and cleanness. Table 3 below shows percentage of energy preference and points out that household's energy choice is considerably different for cooking and lighting. While few energy alternatives are available for cooking purpose, lighting energy sources are mixed and diversified.

Table 3. Primary Lighting and Cooking Energy Source

\begin{tabular}{|l|l|l|l|l|}
\hline \multicolumn{4}{|l|}{ Primary Lighting and Cooking Energy } \\
\hline \multirow{2}{*}{ Energy Source } & \multicolumn{2}{l|}{ Cooking (Ratio) } & \multicolumn{2}{l|}{ Lighting (Ratio) } \\
\cline { 2 - 5 } & Mean & Std. Deviation & Mean & Std. Deviation \\
\hline Electricity & .11 & .309 & .23 & .424 \\
\hline Solar & - & - & .24 & .429 \\
\hline Kerosene & .01 & .081 & .24 & .428 \\
\hline Firewood & .88 & .325 & .02 & .123 \\
\hline Dry cell & - & - & .28 & .449 \\
\hline
\end{tabular}

Regardless of adoption of modern energy sources, households overwhelmingly (more than $88 \%$ ) rely on burning wood to meet their cooking demand. On average, they use 4.7 bundles of firewood $(63 \mathrm{KG})$ in a month for cooking and for lighting purpose. The flame from cooking used as lighting sources. On daily basis, households burn it for 3.78 hour showing high level of exposure to emissions that potentially affect their health and the environment.

Over-reliance on firewood has to do not only with low availability of modern energy in the study areas but also its reliability. Technically speaking, in three out of nine kebelles in both Districts, grid electricity is available. However, many households in these kebelles lack interest to totally embrace it. Of all the households who are connected to the grid, some $60 \%$ rely on firewood as their primary cooking energy choice. Key Informants highlighted that households often feel that cost of cooking with electricity is expensive. In addition, lack of suitable home appliances for using electricity and lack of knowledge of its existence and skill constraint are some of the precarious issues. Frequent power outage reduces reliability to grid electricity too.

Firewood is easily available and be collected freely from communal forests, except the opportunity cost of time during its collection. In fact, $78 \%$ of the households mentioned easy availability of firewood as their primary reason for preferring it over other competing energy sources. Moreover, use of firewood has cultural dimension in that more than $72 \%$ of the households stated that they stick to use it as they feel comfortable when their dish is cooked using 'three stone' fires. This demonstrates that energy interventions aimed at promoting modern energy need to consider cultural constraints as they could militate against adoption. This finding corroborates other studies. (Han, 2014), for instance, argued that "energy 
transition in China is not only a matter of financial issues but also a matter of how people perceive and accept new technology [implying], cultural barriers delay transition." Thus, interventions aimed at bringing energy transition needs to be complex, dynamic and address many precarious issues surrounding households.

Unlike cooking energy, households' lighting energy choice involves more diverse and competing alternatives. It includes firewood, solar energy, kerosene, electricity and dry cell. Some of them are renewable and clean energy sources unlike others. And it involves all sorts of traditional (firewood and kerosene), transitional (dry cell) and modern energy (electricity and solar). Households diversify their lighting energy mix depending on its availability, comfort, price, modernity and efficiency. Both solar energy and kerosene have been used by a quarter of all households (each 24\%). Dry cell is the primary source for great number of people, showing its rapid deployment to rural areas. Peters and Maximiliane (2015) find that dry-cell battery has become available in almost every rural shop of Africa. $52 \%$ of the sampled households that use dry cell have mentioned its easy availability as primary reason for their choice while $48.3 \%$ of the households cited its affordable cost. The use of dry cell is also informed by its portability and thus enhancing security while moving at night. Nearly half of the users (49.3 Percent) cited security advantage as the fundamental reason to employ it in their lighting energy menu. It would be worth to mention that dry cell is used for few hours than other competing lighting sources. For instance, households use electricity, solar and kerosene nearly for 6h/day, $3.71 \mathrm{~h} /$ day, and $4.10 \mathrm{~h} /$ day respectively while for dry cell it stood at $2.90 \mathrm{~h} /$ day.

Table 4. Differences of Continuous explanatory variables between adopter and non-adopters of major lighting energy sources among households using one-way ANOVA (Analysis of Variance)

\begin{tabular}{|l|l|l|l|l|l|l|}
\hline \multirow{2}{*}{ Continuous Variables } & \multicolumn{4}{|l|}{ Primary Lighting Energy } & $\begin{array}{l}\text { Average } \\
\text { Mean }\end{array}$ & \multirow{2}{*}{ Sig. } \\
\cline { 2 - 7 } & Electricity & Solar & Kerosene & Dry Cell & \\
\hline Age of the Head & 40.563107 & 44.528846 & 40.227273 & 41.92 & 41.79638 & 0.0943 \\
\hline Household Size & 4.786408 & 5.211539 & 5.627273 & 4.832 & 5.108597 & 0.0143 \\
\hline Time to Market & .42601942 & .64442308 & .69195455 & .852496 & .66420136 & 0.0000 \\
\hline Time to Main Road & 0.195864 & 0.357221 & 0.6122 & 0.450328 & 0.409407 & 0.0000 \\
\hline Number of Rooms & 2.271845 & 2.394231 & 2.227273 & 1.848 & 2.169683 & 0.0000 \\
\hline Total Land Size & 1.1359223 & 1.7884615 & 1.3818182 & 1.456 & 1.4411765 & 0.0000 \\
\hline Total Livestock Unit (TLU)) & 1.615534 & 3.545481 & 1.709909 & 2.56136 & 2.360611 & 0.000 \\
\hline Ln of total income & 9.986328 & 9.962792 & 9.554718 & 9.569419 & 9.755472 & 0.000 \\
\hline
\end{tabular}

Table 4 presents that electricity is a choice of households with younger age, low household size who lives in areas with market access and closer to the main road. These households possessed few plot of land and Total Livestock Unit (TLU) while they relatively have much income due to their participation in off-farm activities. Solar energy, on the other hand is preferred among elderly households, with moderate household size and income, and relatively close to market and road. And they also have large number of rooms, plot of land and TLU. Households using kerosene as primary lighting energy are relatively young who 
live in remote areas and have low annual income, few TLU and piece of land. Similarly, dry cell is primary choice of lighting among households who are far away from the market and road. They have also houses with few rooms and low income.

Table 5. Differences of dummy explanatory variables for Primary Lighting Energy Choice

\begin{tabular}{|c|c|c|c|c|c|c|c|}
\hline \multirow[t]{2}{*}{ Dummy Variables } & \multicolumn{4}{|c|}{ Primary Lighting Energy Choice } & \multirow[t]{2}{*}{ Percentage } & \multirow[t]{2}{*}{ Chi-Square } & \multirow[t]{2}{*}{ Sig. } \\
\hline & Electricity & Solar & Kerosene & Dry Cell & & & \\
\hline \multicolumn{8}{|l|}{ Woreda } \\
\hline MidaOromo & 73.79 & 54.81 & 9.09 & 70.4 & 52.26 & \multirow[t]{2}{*}{118.0533} & \multirow[t]{2}{*}{0.000} \\
\hline Wonisho & 26.21 & 45.19 & 90.91 & 29.6 & 47.74 & & \\
\hline \multicolumn{8}{|l|}{ Gender } \\
\hline Male & 64.08 & 60.58 & 72.73 & 52.8 & 62.22 & \multirow{2}{*}{10.1553} & \multirow[t]{2}{*}{0.017} \\
\hline Female & 35.92 & 39.42 & 27.27 & 47.2 & 37.78 & & \\
\hline \multicolumn{8}{|l|}{ Primary Occupation } \\
\hline Other & 47.57 & 15.38 & 6.36 & 3.2 & 17.19 & \multirow[t]{2}{*}{93.2558} & \multirow[t]{2}{*}{0.000} \\
\hline Farmer & 52.43 & 84.62 & 93.64 & 96.8 & 82.81 & & \\
\hline \multicolumn{8}{|l|}{ Work Off-farm } \\
\hline No & 38.83 & 64.42 & 71.82 & 82.4 & 65.38 & \multirow[t]{2}{*}{50.1224} & \multirow[t]{2}{*}{0.000} \\
\hline Yes & 61.17 & 35.58 & 28.18 & 17.6 & 34.62 & & \\
\hline \multicolumn{8}{|l|}{ Access To Mobile } \\
\hline No & 13.59 & 25.00 & 41.82 & 56.8 & 35.52 & \multirow[t]{2}{*}{53.2685} & \multirow[t]{2}{*}{0.000} \\
\hline Yes & 86.41 & 75.00 & 58.18 & 43.2 & 64.48 & & \\
\hline \multicolumn{8}{|l|}{ Access to Radio } \\
\hline No & 67.96 & 51.92 & 67.27 & 83.2 & 68.33 & \multirow[t]{2}{*}{25.7707} & \multirow[t]{2}{*}{0.000} \\
\hline Yes & 32.04 & 48.08 & 32.73 & 16.8 & 31.67 & & \\
\hline \multicolumn{8}{|l|}{ Head Education } \\
\hline Illiterate & 32.04 & 48.08 & 34.55 & 54.4 & 42.76 & \multirow[t]{2}{*}{15.9905} & \multirow[t]{2}{*}{0.001} \\
\hline literate & 67.96 & 51.92 & 65.45 & 45.6 & 57.24 & & \\
\hline \multicolumn{8}{|c|}{ Highest Family education } \\
\hline Only reading or less & 23.3 & 27.88 & 20.91 & 40.8 & 28.73 & \multirow[t]{2}{*}{28.7216} & \multirow[t]{2}{*}{0.000} \\
\hline Elementary & 27.18 & 30.77 & 40.91 & 39.2 & 34.84 & & \\
\hline High school or more & 49.51 & 41.35 & 38.18 & 20 & 36.43 & & \\
\hline
\end{tabular}

The findings suggest that primary lighting choice has spatial dimension too. Significant variations were observed among households of the two Woredas. In general, households in Mida Oromo prefer clean energy sources like solar system and electricity than their counterparts in Wonisho Woreda. In sharp contrast to households in Mida Oromo, kerosene continues as dominant lighting energy in Wonisho Woreda. There are also variations among male headed and female headed households in their choice of primary lighting energy in that male headed households consume more of all sorts of lighting energy showing the unequal distribution of decision making and wealth. Choice of kerosene and dry cell among farming households is far greater than non-farming households. Large number of non-farming households (47.6\%) use electricity as their lighting energy sources and this is quite bigger 


\section{Macrothink}

Environmental Management and Sustainable Development

ISSN 2164-7682

2019, Vol. 8, No. 3

than their choice of solar energy (15.4\%), kerosene (6.4\%) and dry cell (3.2\%). Similarly, households who undertake off-farm activity prefer clean energy. While $61.17 \%$ households that engaged in off-farm activity use electricity as their primary energy, only $28 \%$ of them use kerosene as primary lighting energy choice which could be resulted with their capacity to generate modest income.

Access to information has pivotal role in households' endeavour to embrace clean and modern energy. Households with modern communication technologies such as mobile and radio tend to prefer clean energy sources. Electricity, for instance, is chosen as primary lighting energy among $86 \%$ of the households who own mobile cell. To the contrary, only $43.2 \%$ of the same households took kerosene as their lighting energy source. Relatively speaking, people with radio tend to choose solar rather than dry cell, kerosene or electricity.

Education of the head of the household and family members could affect energy transition towards modern and clean ones. While households with literate heads tend to choose electricity than the illiterate ones, the latter choose more of kerosene and dry cell. Household with family members that attained high school or more prefer electricity and dry cell. To the contrary, households posing family members with less education use more of kerosene and dry cell than electricity or solar energy.

\subsection{Household Energy Choice and Income}

This section scrutinizes and discuss energy ladder and energy stacking theory and their explanatory power by looking into whether household's energy choice depends on their income, socio-cultural, demographic and environmental attributes. Succinctly, the relation between these attributes in one hand and a move from traditional fuels to the transitional once and then to modern fuels are explored. How households make decision when choosing one type of energy over the other given their income is one of the central tenets of energy literature (Peters and Maximiliane, 2015; Treiber, 2012). The graph below tries to show patterns of lighting energy use along households' income quartile groups. Household income is calculated by aggregating different sources of income for households and categorizes it to income quartiles taking their relative income as parameter. Accordingly, for the first; the second the third and the fourth income quartile households, the ranges of the annual income are from 1000 Ethiopian Birr (ETB)-10000 ETB; 10,001 ETB-16530 ETB; 16531-30000 ETB; 30001 ETB-95000 ETB respectively. 


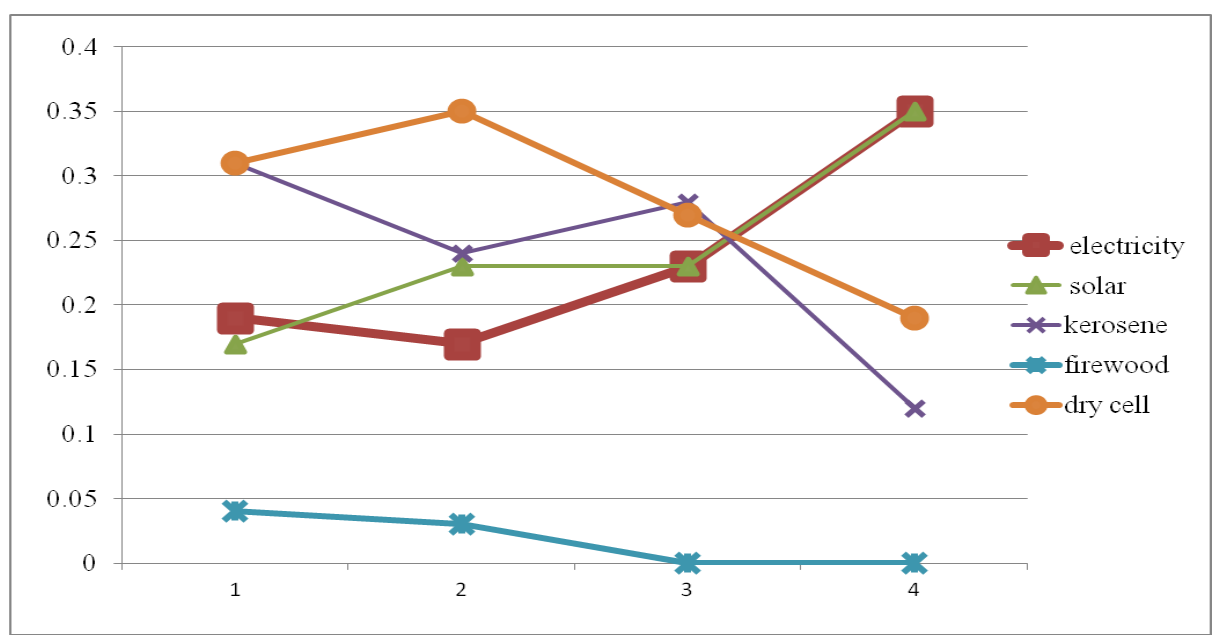

Figure 2. Income Groups (Quartiles) and Lighting Energy

The vertical axis shows proportion of households and the horizontal axis is income quartiles. The graph points out that lighting energy preference varied along income groups. Unlike others, some of the energy sources are choices of well endowed households. Proportion of households in the lower quartile income group is higher for kerosene and dry cell implying that they are preferred among poor households while upper income households use grid electricity and solar for their lighting energy. In comparison to upper income households, lower income households use energy sources that are relatively cheap and easily available. Clean and efficient energy sources, including solar energy and grid electricity are expensive. And, hence, only households in upper income category could afford them. It is worth to mention here that the variation may not simply due to income differences in that other mediating factors are also important.

\subsection{Determinants of Lighting Energy Transition}

Lighting energy choice involves diverse energy systems implying fuel stacking behaviour and dynamics in their use. Thus, thoroughly investigation of major determinants is highly imperative. First, understanding energy consumption pattern is important to increase the use of renewable energy sources (Jean and Aziz, 2015; Han, 2014; Lay et al., 2013), and devise policies aim at promoting them. Second, decisions of household about lighting fuel choice have major impact on the shape of energy systems and on designing interventions (Lay et al., 2013; Zereay et al., 2013). In addition, understanding households' energy transition is critical as this has implications to health of the people and environment (Baiyegunh, 2014; Zereay et al., 2013).

The Multinomial model results are presented in the following table. Solar energy is left out as reference category; thus all the other lighting energy sources are compared with solar energy system. Socio-economic and environmental factors affecting households' decision to choose a specific energy source is presented in the model (Table 6). The choice of variables has been undertaken in line with existing literature and the local context of the study areas. 
Table 6. Parameter Estimates of the Multinomial Model for Lighting Energy Choice

\begin{tabular}{|c|c|c|c|}
\hline Variables & Electricity & Kerosene & Dry Cell \\
\hline Age of the Head & $\begin{array}{l}-0.0303578 * * \\
(0.0136484)\end{array}$ & $\begin{array}{l}-0.0439799 * * \\
(0.0145342)\end{array}$ & $\begin{array}{l}-0.0361572 * * * \\
(0.0122223)\end{array}$ \\
\hline Household Size & $\begin{array}{l}0.1186581 \\
(0.0938632)\end{array}$ & $\begin{array}{l}0.2570022^{* * *} \\
(0.0897301)\end{array}$ & $\begin{array}{l}0.1587323^{*} \\
(0.0850314)\end{array}$ \\
\hline Time to Market & $\begin{array}{l}0.0022173 \\
(0.5379727)\end{array}$ & $\begin{array}{l}0.2417145 \\
(0.5542859)\end{array}$ & $\begin{array}{l}1.212629 * * \\
(0.4541392)\end{array}$ \\
\hline Time to Main Road & $\begin{array}{l}-2.168594 * * * \\
(0.8491056)\end{array}$ & $\begin{array}{l}2.022999 * * \\
(0.697018)\end{array}$ & $\begin{array}{l}1.312485^{*} \\
(0.6407711)\end{array}$ \\
\hline Number of Rooms & $\begin{array}{l}-0.1793495 \\
(0.268273)\end{array}$ & $\begin{array}{l}-0.8244294 * * \\
(0.2970333)\end{array}$ & $\begin{array}{l}-0.7132676^{* *} \\
(0.2435875)\end{array}$ \\
\hline Total Land Size & $\begin{array}{l}-0.1115772 \\
(0.2353758)\end{array}$ & $\begin{array}{l}-0.1763513 \\
(0.2626763)\end{array}$ & $\begin{array}{l}-0.5865508 * * \\
(0.2395921)\end{array}$ \\
\hline TLU & $\begin{array}{l}-0.3553375^{* * *} \\
(0.1040434)\end{array}$ & $\begin{array}{l}-0.3146515^{* * *} \\
(0.1039147)\end{array}$ & $\begin{array}{l}-0.1935051 * * \\
(0.0912217)\end{array}$ \\
\hline Ln of total income & $\begin{array}{l}0.1460817 \\
(0.2671047)\end{array}$ & $\begin{array}{l}-0.4329432 \\
(0.2957697)\end{array}$ & $\begin{array}{l}0.0683274 \\
(0.2621469)\end{array}$ \\
\hline Woreda (Wonisho) & $\begin{array}{l}-1.075104 * * \\
(0.5195571)\end{array}$ & $\begin{array}{l}2.984295 * * * \\
(0.5504935)\end{array}$ & $\begin{array}{l}-0.0325919 \\
(0.4684472)\end{array}$ \\
\hline Gender (Female) & $\begin{array}{l}-0.3842163 \\
(0.3969744)\end{array}$ & $\begin{array}{l}-0.7026518^{*} \\
(0.4142622)\end{array}$ & $\begin{array}{l}-0.2096549 \\
(0.3598636)\end{array}$ \\
\hline Primary Occupation(Farmer) & $\begin{array}{l}-0.6741898 \\
(0.555734)\end{array}$ & $\begin{array}{l}0.9455046 \\
(0.6494026)\end{array}$ & $\begin{array}{l}1.704611 * * \\
(0.7243733)\end{array}$ \\
\hline Work Off-farm (Yes) & $\begin{array}{l}-0.0045813 \\
(0.465876)\end{array}$ & $\begin{array}{l}-0.335318 \\
(0.4655067)\end{array}$ & $\begin{array}{l}-0.714289 \\
(0.4519982)\end{array}$ \\
\hline Access to Mobile (Yes) & $\begin{array}{l}0.8505091 * \\
(0.4716149)\end{array}$ & $\begin{array}{l}-0.5320661 \\
(0.478582)\end{array}$ & $\begin{array}{l}-1.093003 * * * \\
(0.4040036)\end{array}$ \\
\hline Access to Radio(Yes) & $\begin{array}{l}-0.8015118^{*} \\
(0.4389292)\end{array}$ & $\begin{array}{l}-1.399163 * * * \\
(0.4493435)\end{array}$ & $\begin{array}{l}-0.9393133 * * \\
(0.433357)\end{array}$ \\
\hline Education of the Head (Literate ) & $\begin{array}{l}0.4979215 \\
(0.4180444)\end{array}$ & $\begin{array}{l}-0.0457054 \\
(0.4394517)\end{array}$ & $\begin{array}{l}0.5683153 \\
(0.3822373)\end{array}$ \\
\hline $\begin{array}{l}\text { Highest Family Education } \\
\text { (High school or more) }\end{array}$ & $\begin{array}{l}0.8195854 * * \\
(0.3727246)\end{array}$ & $\begin{array}{l}0.0827198 \\
(0.398193)\end{array}$ & $\begin{array}{l}-0.2745564 \\
(0.3696673)\end{array}$ \\
\hline
\end{tabular}

Base Category: Solar Energy

Number of obs $=442$

LR chi2 $(48)=433.81$

Prob $>$ chi $2=0.0000$

Log likelihood $=-394.46681$

Pseudo R2 $=0.3548$

$* * *, * *$ and $*$ are level of significance at $\mathrm{P}<0.001,0.01$ and 0.05 


\section{Macrothink}

Environmental Management and Sustainable Development

ISSN 2164-7682

2019, Vol. 8, No. 3

The study tried to calculate marginal effect of variables (Table 7) that deliver information about the status of the given variable after unit change impact or switching patterns in cases of dummies.

Table 7. Marginal Effects from the Multinomial Logit Model of Lighting Energy Transition

\begin{tabular}{|c|c|c|c|}
\hline Variables & Electricity & Kerosene & Dry Cell \\
\hline Age of the Head & $\begin{array}{l}-0.0007796 \\
(0.00182)\end{array}$ & $\begin{array}{l}-0.0034346^{*} \\
(0.00193)\end{array}$ & $\begin{array}{l}-0.0035103 \\
(0.00231)\end{array}$ \\
\hline Household Size & $\begin{array}{l}-0.0007384 \\
(0.01223)\end{array}$ & $\begin{array}{l}0.0253597 * \\
(0.01134)\end{array}$ & $\begin{array}{l}0.0121556 \\
(0.01552)\end{array}$ \\
\hline Time to Market & $\begin{array}{l}-0.0783971 \\
(0.06909)\end{array}$ & $\begin{array}{l}-.0409294 \\
(0.07011)\end{array}$ & $\begin{array}{l}0.256342 * * * \\
(0.07988)\end{array}$ \\
\hline Time to Main Road & $\begin{array}{l}-0.451316^{* * * *} \\
(0.10223)\end{array}$ & $\begin{array}{l}0.2965135 * * \\
(0.08803)\end{array}$ & $\begin{array}{l}0.291091 * * \\
(0.11506)\end{array}$ \\
\hline Number of Rooms & $\begin{array}{l}0.0429562 \\
(0.03429)\end{array}$ & $\begin{array}{l}-0.074784 * \\
(0.03869)\end{array}$ & $\begin{array}{l}-0.0965303 * * \\
(0.04452)\end{array}$ \\
\hline Total Land Size & $\begin{array}{l}0.0241183 \\
(0.0317)\end{array}$ & $\begin{array}{l}0.0142764 \\
(0.03626)\end{array}$ & $\begin{array}{l}-0.1137171 * * \\
(0.04772)\end{array}$ \\
\hline TLU & $\begin{array}{l}-0.0290583 * \\
(0.01424)\end{array}$ & $\begin{array}{l}-.0242674 * \\
(0.01465)\end{array}$ & $\begin{array}{l}-0.0024223 \\
(0.01811)\end{array}$ \\
\hline Ln of total income & $\begin{array}{l}0.0308963 \\
(0.03495)\end{array}$ & $\begin{array}{l}-.0755536^{*} \\
(0.03896)\end{array}$ & $\begin{array}{l}0.0346164 \\
(0.04901)\end{array}$ \\
\hline Woreda (Wonisho) & $\begin{array}{l}-0.2482886 * * * \\
(0.06794)\end{array}$ & $\begin{array}{l}0.4948369 * * * \\
(0.06743)\end{array}$ & $\begin{array}{l}-0.1362938 \\
(0.0853)\end{array}$ \\
\hline Gender (Female) & $\begin{array}{l}-0.0196035 \\
(0.0515)\end{array}$ & $\begin{array}{l}-0.0818055 \\
(0.0537)\end{array}$ & $\begin{array}{l}0.0205786 \\
(0.06527)\end{array}$ \\
\hline Primary Occupation(Farmer) & $\begin{array}{l}-0.2553617 * * \\
(0.10946)\end{array}$ & $\begin{array}{l}0.0844757 \\
(0.06361)\end{array}$ & $\begin{array}{l}0.2952341 * * * \\
(0.07559)\end{array}$ \\
\hline Work Off-farm (Yes) & $\begin{array}{l}0.0512759 \\
(0.06442) \\
\end{array}$ & $\begin{array}{l}.0080402 \\
(0.05915) \\
\end{array}$ & $\begin{array}{l}-0.1339124 * \\
(0.07804)\end{array}$ \\
\hline Access to Mobile (Yes) & $\begin{array}{l}0.1797239 * * * \\
(0.04831)\end{array}$ & $\begin{array}{l}-0.026676 \\
(0.05927)\end{array}$ & $\begin{array}{l}-0.2574487 * * * \\
(0.07229)\end{array}$ \\
\hline Access to Radio(Yes) & $\begin{array}{l}-0.021168 \\
(0.05359)\end{array}$ & $\begin{array}{l}-0.119628 * * \\
(0.04846)\end{array}$ & $\begin{array}{l}-0.0843176 \\
(0.07687)\end{array}$ \\
\hline Education of the Head (Literate ) & $\begin{array}{l}0.0391884 \\
(0.05397) \\
\end{array}$ & $\begin{array}{l}-.059735 \\
6(0.05715) \\
\end{array}$ & $\begin{array}{l}0.1013255 \\
(0.06953) \\
\end{array}$ \\
\hline $\begin{array}{l}\text { Highest Family Education } \\
\text { (High school or more) }\end{array}$ & $\begin{array}{l}0.1300613 * * * \\
(0.04983)\end{array}$ & $\begin{array}{l}0.0036684 \\
(0.0517)\end{array}$ & $\begin{array}{l}-0.1147871 * \\
(0.06957)\end{array}$ \\
\hline
\end{tabular}

$* * *, * *$ and $*$ are level of significance at $\mathrm{P}<0.001,0.01$ and 0.05

\subsection{Age of the Head of the Household}

Age is an important determinant of lighting energy transition and its effect is statistically 
significant across all lighting energy sources. For a year increase in the age of the household head, odds of selecting electricity as primary lighting energy decreases by 0.97 relative to their choice of solar energy. The marginal effect implies, in comparison to solar energy, an increase in the age of the head by one year decreases probability of choosing electricity by $0.7 \%$ keeping other factors constant. Similarly, the result for kerosene show that for every year added to the age of the head, odds of the households selecting kerosene relative to solar energy decrease by 0.95 . For every year added to the age of the head of the household, preference for kerosene to solar energy decrease by $0.34 \%$ and the effect is statistically significant (at $\mathrm{P}<0.05$ ). The same pattern of preference has been observed in households' decision to switch to dry cell in comparison with solar energy. For a year increase in the ages of the head, the probability of taking kerosene in comparison with solar energy is decrease by $0.35 \%$. It is not a surprise that older households are willing to move to solar energy from kerosene and dry cell as they become older; they tend to have more land and asset. Other studies, however, come up with the finding that an increase in the age of the head of household is less likely to make a household switch from traditional to modern fuels (Jean and Aziz, 2015; Mom and. Tabi, 2011). For these findings, the explanation is that older households are more resistant to change while younger households are more willing to move from traditional energy sources to the modern ones.

\subsection{Family Size of the Household}

Size of the household plays an important role in affecting likelihood of lighting energy transition. Large families are more likely to take kerosene over solar energy and the effect is statistically significant $(\mathrm{P}<0.01)$. In comparison to their choice to solar energy, odds of taking kerosene among households is higher by a factor of 1.3. The marginal effect demonstrates that for every single member added to the household, the probability of choosing kerosene relative to solar energy increases by $2.5 \%$ keeping other variables constant. Similarly, an increase in the size of the household considerably led to more interest for dry cell. For every member added to the household, probability of choosing kerosene increases by $1.2 \%$. Isaac (2014) indicated that household size in Kenya had a negative but significant influence on adoption of solar energy. In Nigeria, (Baiyegunh, 2014), showed that the estimated coefficient for household size is negative and statistically significant for the probability of household transition from traditional to modern energy. This could be explained by the fact that adoption of solar energy requires investment and as such households with large families may spend much of their resources in taking care of children other than investing in solar energy.

\subsection{Access to Market}

Access to market affects probability of households' decision to take modern technology. An increase in one hour of distance from the main market decreases probability of choosing electricity to solar energy by $7.8 \%$. This could be linked with availability of grid electricity in some of the study villages that are closer to urban centers. Similarly, a statistical significant difference is observed in households' preference to dry cell in comparison with solar energy. For each additional hour added to distance from the market, the odds of choosing dry cell as 
primary lighting fuel increases by a factor of 3.75. When households settled in areas far away from the market (for every hour distance), the probability to choose dry cell as lighting energy source is much higher and stood at $25.6 \%$ (significant at $\mathrm{P}<0.001$ ). It is easily portable and increases households' mobility during the night. Both electricity and solar energy systems need to have a market for being chosen among alternatives and the market is rarely available for people living in remote areas.

\subsection{Size of Land}

Ownership of sizable plot of land is an important asset that affects households' decision to adopt new technologies. It provides extra income for each household and hence enables them to afford costs of the technology. In general, households with large plot of land are less likely to prefer lighting sources that could potentially substitute solar energy system. It is expected that large plot of land enables households to prefer grid connected electricity over solar energy. However, the model shows that one-hectare increase in the size of plot of the household decreases probability of choosing electricity by $2.4 \%$. For rich people (in terms of land ownership) solar energy is their preferred choice. This could be linked with low availability of grid electricity in their areas and solar is the only option at their hand at the moment.

When land size of the household head increase by 1 ha, their choice for dry cell decrease by $11.3 \%$ in comparison with solar energy and the difference is statistically significant. Thus, households with relatively large plot of land prefer solar energy over kerosene or dry cell as their primary energy. More land means more wealth which could push them away from kerosene but it could also mean less access to electricity because land is scarce and expensive when households settled in areas closer to market and road. Mutua and Peter (2015), similarly, found that households in Kenya that are relatively well of tend to adopt solar energy.

\subsection{Livestock Resource}

Stock of livestock is one of the determinants of energy transition among rural households. For every TLU added as assets of households, their probability to choose electricity decrease by $2.9 \%$ implying that poor households (in terms of TLU) prefer using solar energy to electricity. Under the current context, households with large livestock stick to adopt solar energy as they are doubtful of connecting to grid electricity in the near future and their viable option is solar energy. In addition, more livestock implies more pasture which is found in remote areas and hence less access to grid electricity. Having large livestock population enables them to replace kerosene with solar energy. For every TLU added, it decreases probability of taking kerosene by $2.4 \%$ and its effect is found to be statistically significant. Again, TLU provides opportunity to seize solar energy more than dry cell. For, every TLU added, probability of taking dry cell decreases by $0.2 \%$.

\subsection{Income of the Household}

One of the central tenets energy literature is its overstated argument on the profound impact of income on household energy transition. As expected, households' preference to electricity, in comparison to solar energy, is found to be positive but not statistically significant implying 
that households do not consider solar energy as inferior. It is usually claimed that well endowed households could decide to embrace electricity than solar energy as they can afford the costs of connecting to grid electricity and the monthly consumption bill. Other researchers have also reached to the same conclusion. Jean and Aziz (2015) finds income was statistically significant only at $10 \%$ for households in Cameron while other factors were more significant in the move to cleaner fuels.

Argument of the energy literature best suited to in the context of solar choice vis a vis kerosene. The model shows that income plays a key role in choosing clean and relatively expensive energy source. The rise of income of households corresponds with low tendency to use kerosene in comparison with their desire to install and use solar technology as lighting fuel. The marginal effect shows that for every rise in income of the household by 1000 ETB, the probability of households for taking kerosene relative to solar energy is going to decrease by $7.5 \%$ and the effect is statistically significant. The rise in income guarantees individuals to pay a lump sum for solar energy system.

\subsection{Access to Road}

Access to road is one of the key factors affecting household energy transition. It provides opportunities for selecting one type of energy over the other. Its effect, in comparison with solar energy, is statistically significant along all lighting energy types. Households' settled in areas far away from the road are less likely to adopt electricity. From the MNL model, for each hour distance from the main road, the probability of choosing electricity as primary lighting energy is decrease by more than $45 \%$. Households in remote villages have less opportunity to connect to grid electricity and, even if it is available, costs of connection increase along the distance from the road. For households living in distant villages, kerosene is their preferred choice. For every hour distance, household probability to choose kerosene increases by $29.6 \%$ relative to their choice of solar energy. Similarly, households that rarely connected to road infrastructure prefer dry cell to solar energy. The odds of choosing dry cell is 3.72 times. The marginal effect shows that living in one-hour distance from the main road increases probability of switching to dry cell by $29 \%$.

\subsection{Number of Rooms}

Size and type of house of the household affects its lighting energy choice (Jean and Aziz, 2015). For every room added to the house, their probability of choosing kerosene decreases by 7.4 percent. Similar to kerosene, probability of choice of dry cell significantly increase when the house has much rooms. The marginal effect for the number of rooms of the household shows their low preference to dry cell for lighting purpose in comparison with solar energy. For every room added, household probability of adopting dry cell decreases by 9.6 percent. Comparing to solar energy, households have low appetite for dry cell when room number of houses increase. And, the difference is statistically significant, $\mathrm{P}<0.01$.

\subsection{Place of Households}

In comparison to respondents in Wonisho Woreda, Households in Mida Oromo are more likely to choose electricity as their primary lighting choice relative to solar energy and the 
effect is statistically significant $(\mathrm{P}<0.01)$. The model shows that, keeping other factors constant, living in Wonisho Woreda decreases households' probability of taking electricity by $24.8 \%$. On the other hand, households in Wonisho woreda are more likely to choose kerosene as their primary lighting energy choice than solar energy and the difference is statistically significant $(\mathrm{P}<0.001)$. Comparing with respondents in Mida Oromo Woreda, a household in Wonisho Woreda has nearly 20 times odds of choosing kerosene as opposed to solar energy to meet their lighting energy demand. The marginal effect shows that being in Wonisho Woreda increases probability of taking kerosene by $49.5 \%$ and the effect is statistically significant. Considerable share of households in Wonisho Woreda is still using kerosene, but given the trends in battery usage rates, this can be expected to decrease in the near future. This result is consistent with other findings on significant impact of geography/zones on kerosene choice and consumption (Peters and Maximiliane, 2015). Ogwumike (2014) for instance, showed existence of positive association between living in the Southern Zones of Nigeria and kerosene consumption; where as there is negative association between living in the Northern Zones of Nigeria and kerosene consumption. Households in Wonisho Woreda have less appetite to take dry cell as their primary lighting energy. Comparing to preference of solar energy system, choice of dry cell as primary lighting energy decreases by $13.6 \%$ among households in Wonisho woreda.

\subsection{Gender of the Head}

Probability of choosing electricity over solar energy decreases by $2 \%$ among female headed households. Yet the result is not statistically significant. This finding coincides with Jean and Aziz (2015) who found that, in Cameron gender is not significant variable in households' energy choice from transitional to modern ones. To the contrary, female headed households prefer solar energy over kerosene. The marginal effect of the model indicates that for female headed households, probability of choosing kerosene over solar energy decrease by $2.8 \%$ and the effect is statistically significant. Female are exposed to health threats from kerosene and solar energy gives them relief by improving indoor air quality; this was also the case in Nigeria in which female headship of a household affects kerosene use negatively (Ogwumike, 2014).

\subsection{Primary Occupation}

Type of occupation of head is an important factor affecting lighting energy choice of the household. The model shows that households who do not take farming as primary occupation tend to take clean and modern energy. Households who primarily engaged in agriculture are less likely to embrace electricity than solar energy. To be specific, being a farmer decreases probability of choosing electricity over solar energy by $25.5 \%$ and the result is statistically significant $(\mathrm{P}<0.01)$ showing that solar is the choice of farming households. This could be associated with low availability and the relative expensiveness of connecting to grid electricity as farmers live in areas far away from the grid. This finding is in direct contradiction to other studies concluding that engaging in non-agriculture and other formal employment has positive effect on solar adoption (Mutua and Peter, 2015). Similarly, dry cell is one of the preferred lighting energy among farming households. Comparing to solar energy, 
probability of adopting dry cell increase by $29.5 \%$ and the effect is significant $(\mathrm{P}<0.001)$. Non-farming households tend to pick dry cell less than solar energy when they are compared with those whose occupation is primarily farming. Households participating in off-farm jobs tend to prefer modern and clean energy; primarily to electricity and then to solar energy. Similarly, comparing with their solar energy uptake, these households have less appetite to deploy kerosene and dry cell. Engaging in off-farm activity increase the probability of taking electricity by $5 \%$ while it decreases the probability of choosing kerosene and dry cell by $0.8 \%$ and $13.4 \%$.

\subsection{Access to Mobile Technology and Radio}

Ownership of mobile technology affects choice of primary lighting energy. Households with mobile technology tend to choose electricity than solar energy for their lighting activity. Odds of adopting electricity among households who possess mobile cells is 2.34 times in comparison with people who did not possess the technology. And, the difference is statistically significant $(\mathrm{P}<0.05)$. From the marginal effect of the model, mobile ownership increases probability of adopting electricity nearly by $18 \%$. Similarly, mobile cell ownership decreases probability of using dry cell by $25 \%$. This could be linked with the fact that mobile technologies have torches and in some of the households, they use it as lighting option. Households with radio are less likely to choose electricity than solar energy when compared with those households without radio. The difference is statistically significant $(\mathrm{P}<0.05)$. This could be associated with their connectivity to electricity enables them to use television as source of information and entertainment, and, thus they relied less on radio. The same hold true for choice of kerosene and dry cell in comparison with solar energy systems. People with radio are less likely to adopt kerosene than solar energy system as their lighting source. These people tend to prefer clean energy as they may get knowledge about the adverse health and environmental impacts associated with the use of kerosene. The marginal effect reveals that radio ownership decrease probability of using kerosene by around $12 \%$ and the effect is statistically significant $(\mathrm{P}<0.01)$. In the same vein, radio ownership tends to decrease use of dry cell as lighting energy. In comparison to solar energy choice, radio ownership decrease probability of using dry cell by $8.4 \%$. Access to modern communication technologies, including mobile cells and radio, could positively affect adoption of energy sources that are clean and modern i.e. solar technology and electricity. Effect of these technologies on energy choice could be linked to provision of information about their availability. Households may get lessons about contribution of modern energy sources on their livelihood and the environment. Knowledge of households may increase as a result of the information they collect through radio and mobile technology. On the other hand, mobile and radio become more effective and reliable when households run them using modern energy.

\subsection{Education}

Level of education of the head of the household or family members affect their decision to prefer one energy type over another. The MNL model shows that literate households prefer modern, clean and more expensive energy than illiterate ones. Odds of choosing electricity among literate households is 1.65 times more than illiterate households. When households 
have accesses to basic education, probability of adopting electricity increases by $3.9 \%$ in comparison to their solar energy choice. Comparing literate and illiterate household heads reveal that choice of kerosene decrease by $5.9 \%$ for the former. A possible reason for this finding is that education enhances individual's awareness of the detrimental consequence of using kerosene on their health and environment.

Educational status of family members of the household is also equally important in affecting choice of modern energy, including solar energy system. Households with well educated family members tend to prefer clean and expensive energy sources. The marginal effect suggests that likelihood of choosing electricity among households that comprise members with high school or more education increase by $13 \%$ and the difference is statistically significant $(\mathrm{P}<0.001)$. To the contrary, households with family members with low educational attainment tend to choose kerosene or dry cell than solar energy for meeting their lighting energy demand. The marginal effect suggests that for every family member with high school or more added to the household, probability of taking dry cell will decrease by $11.5 \%$ (in comparison with solar energy). Thus, the model shows that higher educational attainment of member of the household increases probability of using clean fuels and less appetite for using traditional and polluting fuels. Higher level of education improves knowledge of fuel attributes, tastes and preferences for better fuels. These findings are congruent with other studies. Zereay et al., 2013), for instance, found that in rural Kisumu in Kenya energy switching is higher among educated heads. Isaac (2014) argued that secondary and primary level education significantly influences adoption of solar energy in Kenya. Baiyegunh (2014), in Nigeria, show a unit increase in the years of household head's education increase the likelihood of transition from traditional to modern once by about $18 \%$. Studies by Mekonnen and Köhlin, (2008 ); Gebreegziabher et al. (2011) in Ethiopia and by Farsi et al. (2007) in India came up with similar findings that households with more educated members are more likely to choose cleaner fuels. Jean and Aziz (2015) in Cameron found that households whose members have primary and secondary educations are more willing to adopt cleaner fuels.

\section{Conclusion and Policy Implications}

Households employed multiple energy sources to undertake lighting activity showing energy stacking is the preferred theory in reflecting trends of lighting energy choices. The study shows that households combine and consume all sorts of traditional, transitional and modern energy and the associated expenditure varied depending on their income. While households in top echelon of income category prefer clean and relatively expensive lighting energy sources, households in lower income brackets tend to opt to energy sources that are cheap and easily accessible. In general, the proportion of households in lower quartile income group is higher for kerosene and dry cell which implies that poor households consume more of kerosene and dry cell as their primary lighting energy while upper income households use electricity and solar for their lighting energy end. The multinomial logit model demonstrates that demographic characteristics, social attributes, spatial factors, and access to information and communication technologies are as equally important as income in affecting lighting energy transition. In addition to income and education, households who are older and few family size, with access to market and road, owing sizable plot of land and livestock; living in Wonisho 
District and engaging in non-farming activities are important factors that are more likely affect households' choice of modern energy such as grid electricity and solar energy systems than traditional energy sources, including kerosene. Thus, any interventions aimed at providing modern energy sources need to consider diverse factors and local contexts. Firstly, a single energy source is not sufficient enough to meet all their lighting energy demand and they often keep multiple energy sources at a time showing that energy sources are complementary with each other. Second, information is vital in achieving transitions toward modern and clean energy and thus highly imperative to promote all. Third, context matters in lighting energy transition.

\section{References}

Abdul-Salam,Y. (2014). Access to Electricity in Sub-Saharan Africa. Modeling the Importance and Adoption of Off-grid Renewables. University of Aberdeen, UK.

Ahlborg, H., \& Linus, H. (2011). Drivers and Barriers to Rural Electrification in Tanzania and Mozambique: Grid Extension, Off-grid and Renewable Energy Sources. World Renewable Energy Congress, Policy Issue, 8-13, 2493-2500.

https://doi.org/10.3384/ecp110572493

Arora, A., Garima, J., \& Vivek, J. (2011). Universal access to energy: a pre-requisite for achieving the Millennium Development Goals. The Energy and Resources Institute, New Delhi.

Baiyegunh, L. (2014). Rural Household Fuel Energy Transition: Evidence from Giwa LGA Kaduna State, Nigeria. Energy for Sustainable Development, 20, 30-42.

https://doi.org/10.1016/j.esd.2014.02.003

Baiyegunh, L. J. S., \& Hassan, M. B. (2014). Hassan Rural household fuel energy transition: Evidence from Giwa LGA Kaduna State, Nigeria. Energy for Sustainable Development, 20, 30-35. https://doi.org/10.1016/j.esd.2014.02.003

Batinge, B., Musango, J. K., \& Brent, A. C. (2017). Leapfrogging to Renewable Energy: The Opportunity for Unmet Electricity Markets. South African Journal of Industrial Engineering, 28(4), 32-49. https://doi.org/10.7166/28-4-1702

Bawakyillenou, S. (2007). Rural Electrification in Ghana. Issues of Photovoltaic EnergyTechnology Utilization. University of Hull.

Berg, B. L. (2001). Qualitative Research Methods for the Social Sciences. 4th edi. California State University, Long Beach.

Beyene, A. D., \& Koch, S. F. (2012). Clean Fuel Saving Technology Adoption in Urban Ethiopia. Energy Economics, 36, 605-613. https://doi.org/10.1016/j.eneco.2012.11.003

Central Statistical Authority (CSA) (2012). Agricultural sample survey 2011/2012, Volume IV: Report on Land Utilization, Central Statistical Agency, Addis Ababa, Ethiopia.

Central Statistical Authority (CSA) (2007). The 2007 Population and Housing Census of 
Ethiopia. Addis Ababa, Ethiopia.

Central Statistical Authority (CSA) and the World Bank (WB) (2013). Ethiopia Rural Socioeconomic Survey (ERSS): Survey Report. Addis Ababa, Ethiopia .

Dawit, D. (2015). Bio-Based Energy, Rural Livelihoods and Energy Security in Ethiopia. PL Academic Research, Frankfurt (2015).

Dawit, D. G., Jose, J., Narayan, A., Chen, Q., Varun, G., \& Alisher, M. (2015). Decentralized Energy in Water-Energy-Food Security Nexus in Developing Countries: Case Studies on Successes and Failures. ZEF-Discussion Papers on Development Policy No. 203,. Bonn, Germany .

Eduardo, R-O., \& Rigoberto, A. Y-G. (2014). Income and Energy Consumption in Mexican Households. Policy Research Working Paper, 6864, WB, Latin America and Caribbean Region.

Farsi, M., Filippini, M., \& Pachauri, S. (2007). Fuel choices in urban Indian households. Environ. Dev. Econ., 12, 757-774. https://doi.org/10.1017/S1355770X07003932

Gebreegziabher, Z., Mekonnen, A., Kassie, M., \& Köhlin, G. (2011). Urban energy transitio and technology adoption: the case of Tigrai, Northern Ethiopia. Energy Economics, 34, 410-418. https://doi.org/10.1016/j.eneco.2011.07.017

Getaw, T., Godfrey, B., \& Wondwosen, T. (2015). Impacts of Fuel Efficient Improved Cooking Stove on Biomass Collection and Consumption in Rural Ethiopia. Paper presented at Tropentag, September 16-18, 2015, Berlin, Germany. [Online] Available: www.tropentag.de/2015/abstracts/links/Tefera_GMUZQtoU.pdf

Ghosh, D., Shukla, P. R., Garg, A., \& Ramana, V. (2002). Renewable energy technologies for the Indian power sector: mitigation potential and operational strategies. Renewable and Sustainable Energy Review, 6, 481-512. https://doi.org/10.1016/S1364-0321(02)00015-1

Han, S-Y. (2014). Migration, Livelihood, and Energy Transition of Rural Farming Households. Arizona State University: Center for Population Dynamics.

He, P. (2014). The Determinants of Renewable Energy Technology Adoption: Empirical Evidence from China. Zurich, Switzerland.

Howell, J. (2011). Rural Electrification and Renewable Energy in Ethiopia. Environmental Policy Group in the Environmental Studies Program at Colby College in Waterville, Maine.

International Energy Agency (2012). Africa Energy Outlook: A Focus on Energy Prospects in Sub-Saharan Africa. World Energy outlook Special Report. Paris, France. International Energy Agency. The Energy Development Index. World Energy Outlook. [Online] Available: http://www.iea.org/publications/worldenergyoutlook/resources/energydevelopment/theenergy developmentindex/. Accessed 30 May 2017

Isaac, G. (2014). Determinants of Adoption of Renewable Energy in Kenya. A Research Paper Submitted to the School of Economics, University of Nairobi. 
Jean, H. N., \& Aziz, K. K. (2015). Modelling Fuel Choices among Households in Northern Cameron. Sustainability, 7, 9989-999. https://doi.org/10.3390/su7089989

Kothari, C. R. (2004). Research Methodology: Methods and Techniques. New Age International (P) Ltd., Publishers.

Kowsari, R. (2013). Twisted Energy Ladder: Complexities and Unintended Consequences in the Transition to Modern Energy Services. University of British Columbia.

Lay, J., Ondraczek, J., \& Stoever, J. (2013). Renewables in the energy transition: evidence on solar home systems and lighting fuel choice in Kenya. Energy Econ., 40, 350-9.

https://doi.org/10.1016/j.eneco.2013.07.024

Lighting Africa Program (2013). Ethiopia Market Intelligence. Addis, Addis Ababa, Ethiopia.

Malla, S., \& Govinda, R. T. (2014). Household Cooking Fuel Choice and Adoption of Improved Cookstoves in Developing Countries: A Review. WB; Development Research Group; Policy Research Working Paper 6903. https://doi.org/10.1596/1813-9450-6903

Marshall, M. N. (1996). Sampling for Qualitative Research. Family Practice, 13, 522-525. https://doi.org/10.1093/fampra/13.6.522

McFadden, D. (1974). Conditional Logit Analysis of Qualitative Choice Behavior. In: P. Zarembka (ed.), Frontiers in Econometrics, Chapter 4, 105-142, Academic Press, New York.

Mekonnen, A., \& Köhlin, G. (2008). Determinants of Household Fuel Choice in Major Cities in Ethiopia. Environment for Development Discussion Paper Series, EfD/RFF DP 08-18.

Mida Oromo Economic Office (2017). Socio-Economic Profiles of Mida Oromo Woreda. Meragna Town.

Ministry of Water and Energy(MoWE) (2012). Scaling - Up Renewable Energy Program. Ethiopia Investment Plan (Draft Final), Addis Ababa, Ethiopia.

Ministry of Water and Energy(MoWE) (2016). Draft Proposal Requesting Funding from World Bank to Rural Electrification. Addis Ababa, Ethiopia.

Mom, N. A., \& Tabi, A. J. (2011). An Analysis of Domestic Cooking Energy Choices in Cameroon. Eur. J.Soc. Sci., 20, 336-347.

Mutua, J., \& Kimuyu, P. (2015). Kimuyu Household Energy Conservation in Kenya: Estimating the Drivers and Possible Savings. Environment for Development, Discussion Paper Series, EfD DP 15-04.

Mwangi, M., \& Samuel, K. (2015). Factors Determining Adoption of New Agricultural Technology by Smallholder Farmers in Developing Countries. Journal of Economics and Sustainable Development, 6(5), 208-216.

Narasimha, R., Anjana, A., and Davida, W. (2017). Impacts of small-scale Electricity Systems: A study of Rural Communities in India and Nepal. World Resource Institute. 


\section{Macrothink}

Nussbaumer, P., Bazilian, M., \& Modi, V. (2012). Measuring Energy Poverty: Focusing on What Matters. Renewable and Sustainable. Energy Reviews, 16, 231-243. https://doi.org/10.1016/j.rser.2011.07.150

Ogwumike, F., Uchechukwu, O., \& Gabriel, A. (2014). Household Energy Use and Determinants: Evidence from Nigeria. International Journal of Energy Economics and Policy, $4(2), 248-262$.

Osiolo, H. (2009). Enhancing Household Fuel Choice and Substitution in Kenya. The Kenyan Institute of Public Policy Research and Analysis, Discussion Paper102, Nairobi.

Overseas Development Institute (2015). Accelerating access to electricity in Africa with off-grid solar: Off-grid solar country briefing. Ethiopia. UK, London.

Peters, J., \& Maximiliane, S. (20105). Impacts of Rural Electrification Revisited - The African Context. Ruhr Economic Papers, No.556. Bochum, Germany.

Pundo, M., \& Fraser, G. (2006). Multinomial logit analysis of household cooking fuel choice in rural Kenya: The case of Kisumu district. Agrekon, 45(1), 24-37.

https://doi.org/10.1080/03031853.2006.9523731

Pode, R. (2013). Financing LED Solar Home Systems in Developing Countries. Renew Sustain Energy Rev., 25, 596-629. https://doi.org/10.1016/j.rser.2013.04.004

Reddy, S. (2004). Economic and Social Dimensions of Household Energy Use: A Case Study of India. In Ortega, E. \& Ulgiati, S. (Eds.), Proceedings of IV Biennial International Workshop “Advances in Energy Studies” (pp. 469-477). Unicamp, Campinas, SP, Brazil.

Samad, H. A., Khandker, S. R., Asaduzzaman, M., \& Mohammad, Y. (2013). The Benefits of Solar Home Systems: An Analysis from Bangladesh. The World Bank Development Research Group. https://doi.org/10.1596/1813-9450-6724

Schelly, C. (2014). Residential solar electricity adoption: What motivates, and what matters?. A Case study of early adopters. Energy Research and Social Science, 2, 183-191. https://doi.org/10.1016/j.erss.2014.01.001

Schelly, C. (2015). Frameworks for Understanding and Promoting Solar Energy Technology Development. Resources, 4, 55-69. https://doi.org/10.3390/resources4010055

Sehjpal, R., Aditya, R., Anmol, S., Saptarshi, D., \& Ritu, S. (2014). Rural Energy Transitions: Insights from Madhya Pradesh. The Energy and Resources Institute: TERI-NFA Working Paper.

Sheilah, M., \& Patrice, N. (2005). The Impact of Energy Use on Poor Urban Livelihoods in Arusha, Tanzania. Development Planning Unit, London.

Treiber, M. (2012). Fuel and stove diversification in the light of energy transition and technologyadoption theory. Norweigan University of Science and Technology.

Wonisho Woreda Economic Office (2017). Socio-Economic Profiles of Wonisho Woreda. 


\section{Macrothink \\ Environmental Management and Sustainable Development \\ ISSN 2164-7682 \\ 2019, Vol. 8, No. 3}

Bokasa Town.

World Bank (2008). The Welfare Impact of Rural Electrification: A Reassessment of the Costs and Benefits. World Bank, Washington.

Yonas, A., Abebe, D. B., Gunnar, K., \& Alemu, M. (2013). Household Fuel Choice in Urban Ethiopia: A Random Effects Multinomial Logit Analysi. Environment for Development, Discussion Paper Series 13.

Zereay, T., Marion, D., Patricia, V. T., \& Fiona, L. (2013). Mainstreaming sustainable energy access into national development planning: The case of Ethiopia. Stockholm Environment Institute; Working paper No.09.

\section{Copyright Disclaimer}

Copyright for this article is retained by the author(s), with first publication rights granted to the journal.

This is an open-access article distributed under the terms and conditions of the Creative Commons Attribution license (http://creativecommons.org/licenses/by/3.0/). 